\title{
DE OBJETO A SUJETO. LOS ESCLAVOS ANTE LA LEGISLACIÓN Y EL PODER COLONIAL EN CENTROAMÉRICA, 1532-1600. OBANDO ANDRADE, RAFAEL. SAN SALVADOR, EL SALVADOR: UCA EDITORES, 2019
}

Dorde Cuvardic García

Escuela de Filología, Lingüística y Literatura Universidad de Costa Rica, Costa Rica

Este libro investiga la participación de Centroamérica en la llamada esclavitud atlántica, la "tercera meseta" de la esclavitud, en terminología de Michael Zeuske, que se desarrolló entre los siglos XVI y XIX. En particular, la obra se centra en la etapa inicial de este proceso: el siglo XVI.

En la "Introducción", Rafael Ángel Obando declara dos de los intereses que han guiado su investigación: visibilizar la participación de la población afrodescendiente en la construcción de la sociedad colonial centroamericana (junto con los indígenas y los españoles) y, asimismo, destacar que los últimos no fueron un colectivo sin capacidad para movilizar los procesos históricos, sino un grupo social con una gran fuerza para emprender tácticas de empoderamiento y de subversión contra las autoridades coloniales españolas.

El Capítulo 1, "La esclavitud en el nacimiento jurídico de América", se dedica a explicar las causas próximas que provocaron el surgimiento del tráfico a gran escala de los sujetos esclavizados desde África, sobre todo las leyes de protección jurídicas contra la esclavitud directa del indígena americano, las llamadas Leyes Nuevas. Para ahondar en el tratamiento jurídico del sujeto esclavizado de origen africano en América es necesario retroceder al sistema español medieval, que a su vez mediatizó el tratamiento conferido a los indígenas. Todas las acciones estuvieron encaminadas a regular la fuerza laboral en las tierras americanas una vez incorporadas sus poblaciones al sistema de mundo del modo de producción capitalista en su etapa inicial, el mercantilismo.

Muy importantes, como señala Rafael Obando, son dos procesos que se dan simultáneamente y que están interrelacionados: mientras la Corona emitió decretos y ordenanzas para convertir en ilegal el uso de la mano de obra indígena esclava, al mismo tiempo recomendó el uso de esclavos procedentes de África. De esta manera, 
la Corona respondió a las protestas de los conquistadores ante el colapso de la naciente economía extractiva en Centroamérica por la escasez de trabajadores. Es una legislación que no tuvo un gran efecto práctico; de hecho, la esclavitud indígena convivió con la naciente esclavitud africana por mucho tiempo.

El enfoque de este capítulo es jurídico, aunque también se explican con detenimiento las consecuencias económicas del complejo entramado de relaciones laborales. El nuevo modelo de esclavitud africana es descrito con detalle por Rafael Obando desde la compra en África, hasta el transporte y venta en América. Con todo el cinismo y la mala fe, para "lavar" las propias culpas, los europeos buscaron -con leyes originadas en el derecho romano- la compra de esclavos que eran prisioneros de las guerras locales en África, entre otras vías. Rafael Obando dedica un muy pertinente apartado a las razones esgrimidas desde la Iglesia católica, con toda la ambivalencia del caso, en favor y en contra de la esclavitud indígena y africana.

Este mismo capítulo introduce algunas tácticas de empoderamiento del sujeto africano esclavizado en América, aquellas surgidas de las posibilidades ofrecidas por el hecho de ser sujetos evangelizados. Por ejemplo, señala Obando, el adoctrinamiento en la fe católica fue aprovechado por los esclavos urbanos para constituir sociedades de ayuda mutua y articular procesos de resistencia. La necesidad de sobrevivir permitió entender a los esclavos africanos que las leyes eclesiásticas, si eran reivindicadas como propias, permitían ofrecer espacios de ayuda y de libertad para soportar su terrible situación, tanto al interior de la comunidad de los sujetos esclavizados como en su relación con la sociedad hegemónica. Paradójicamente, a lo largo de la Colonia, los indígenas partían en principio de una condición jurídica más favorable, pero fue la población de origen africano la que obtuvo a largo plazo mayores puestos de responsabilidad en la era colonial.

El Capítulo 2, "Primeros derechos, primeras luchas", se centra en la legislación que amparó la entrada de los primeros esclavos africanos a Centroamérica. También se dedica esta sección a los castigos impuestos por el aparato jurídico que regulaba la esclavitud, así como las posibilidades de manumisión y los "derechos" que en principio tenían a su disposición los esclavos africanos, aunque en ocasiones no se llevaban a la práctica. Por ejemplo, el sujeto esclavizado tenía la posibilidad de recurrir a la protección de la Iglesia o del sistema jurídico, de comprar su libertad o de recibir del amo un peculio o pequeña parcela de tierra.

Asimismo, quedó regularizada la obligación de los propietarios de darles a los esclavos una educación religiosa y de garantizar el cuido de los esclavos ancianos. El sujeto esclavo tuvo status jurídico y, como tal, tuvo posibilidad de defenderse, por lo menos en el papel -dentro del sistema colonial-, de los abusos que recibía, por lo que las denuncias fueron aumentando a lo largo de la época colonial. Con una condición ambigua de mercancía y de sujeto jurídico, Obando destaca que los africanos tuvieron numerosos papeles en la Centroamérica colonial: además de esclavos, también fueron 
sujetos libres y en ambos casos se desempeñaron como soldados, capataces, ganaderos, curtidores.

En todo caso, la benevolencia hacia el esclavo estuvo muchas veces ausente de la vida cotidiana; los castigos y la punición como azotes y mutilaciones, sobre todo, fueron la norma. El régimen de violencia permanente del sistema colonial se constituyó en una justificación más para la huida y el establecimiento de los palenques de los cimarrones. Las complejas relaciones entre los jefes de estos últimos y las autoridades españolas se explican con todo detalle en este segundo capítulo. Eran épocas en las que se permitía implícitamente la existencia de los palenques, ya que se convertían en importantes mediadores en el comercio de contrabando, tan necesario para la sobrevivencia de las colonias españolas. Esos tiempos se alternan con otros en los que se buscaba su disolución.

También explica Rafael Ángel Obando las primeras revueltas de esclavos africanos en Centroamérica, principalmente en el actual territorio de Honduras, donde sufrían una recurrente explotación en los lavaderos de oro. La constante huida de sujetos esclavizados africanos y sus alianzas con los indígenas son acciones que provocaron importantes pérdidas económicas a los propietarios de los lavaderos. Francisco de Montejo, Alonso de Maldonado y Alonso Funes fueron autoridades españolas encargadas de la "pacificación" del territorio ante la existencia de revueltas y palenques.

El Capítulo 3, "Panamá: arteria del Imperio", se dedica a analizar la importancia de Panamá en el comercio de esclavos. Además, se ofrece una sección sobre el uso de sujetos esclavizados de origen africano en la pesca de las perlas, en la actual Panamá, una vez que quedaron diezmadas las poblaciones de indígenas. Asimismo, se analizan diversas fugas y rebeliones de esclavos en la región, lo que resultó en el surgimiento del fenómeno del cimarronaje y la creación de los palenques, ya mencionados, un sistema de organización social encabezado por caudillos que se enfrentó al poder colonial. Dos ejemplos sobre los que se detiene el autor son la resistencia dirigida por Felipe Capitán de Conchas "Felipillo" y el asentamiento cimarrón del rey Ballano.

El poder colonial no fue monolítico. De hecho, Rafael Obando explica los disensos entre la Corona, la Iglesia y los colonizadores al organizar la mano de obra empleada en el sistema económico colonial. El Capítulo 3 está dedicado a analizar las distintas respuestas que las autoridades españolas emplearon para enfrentar el fenómeno del cimarronaje y las distintas alianzas (vinculadas al contrabando) que establecieron los cimarrones con los indígenas y los piratas, una vía para consolidar y promover los espacios de libertad.

Las reflexiones finales nos ofrecen una síntesis interpretativa excelente del libro: la progresiva naturalización de la esclavitud de origen africano en Centroamérica, las tácticas de resistencia de los esclavos y el cimarronaje. El negro es un importante actor activo, no pasivo, en la historia centroamericana. La principal contribución de este li- 
bro -que tiene imágenes ilustrativas de los procesos, argumentados con claridad y espíritu didáctico- radica en presentar una visión del sujeto esclavizado y del cimarrón como un actor social relevante en la historia colonial centroamericana. Además, destaca la importancia del Pacífico en la economía esclavista centroamericana, frente al Atlántico, y presta atención a una época no estudiada suficientemente, como son los inicios de la Colonia (primero y segundo tercio del siglo XVI), frente a los siglos XVII y XVIII.

Este libro cuenta con una introducción del catedrático Javier Laviña, de la Universidad de Barcelona -uno de los más importantes docentes e investigadores del tema de la esclavitud a escala internacional-, y no solo está dirigido a académicos que investigan la presencia africana en Centroamérica, sino también a las organizaciones y a la población afrodescendiente del istmo y a todos los ciudadanos que quieran conocer los orígenes de esta región transcultural.

Dorde Cuvardic García. Costarricense-español. Profesor e investigador de la Escuela de Filología, Lingüística y Literatura de la Universidad de Costa Rica (UCR). Docente del Doctorado en Estudios de la Sociedad y la Cultura (UCR). Es Doctor en Periodismo y Ciencias de la Comunicación de la Universidad Autónoma de Barcelona y Magister en Literatura Española de la UCR. Fue Director de la Maestría en Comunicación (UCR) entre el 2003 y el 2005.

Contacto: dorde.cuvardic@ucr.ac.cr

ORCID: https://orcid.org/0000-0002-6448-9058 